\title{
The Theoretical and Practical Challenges of European Security Community in the Context of Globalisation
}

\section{Virginijs Keinis}

Rīga Stradinš University, 16 Dzirciema Street, Rīga, LV-1007, Latvia

E-mail:virginijs.keinis@gmail.com

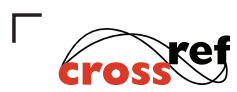

http://dx.doi.org/10.5755/j01.eis.0.11.18129

Modern world and the inconsistent process of globalisation have given new dimensions to matters like national self-confidence, identification with a certain ethnos, traditions, symbols and history. Due to a number of factors borders have ceased to exist literally and figuratively.

During the foundation and enlargement of modern Europe regional policy was mostly economically driven. It was declared that Europe has never been as prosperous, secure and free. Today we start to doubt this declaration and it is clear that history has brought us challenges that the founders of Europe could not imagine.

What are the results of Europe's "open door" policy, Schengen treaty and common financial, energy and transit policy? What exactly is the common foreign security policy and how successful it can be in the fast changing environment of today's world?

All these aspects have determined the need to shift emphasis of policy from economics to security and conceive the context of practically unlimited information space, the aggressive propaganda of hostile states (or pseudo states) and endless flow of refugee's that contribute to international terrorism and national disturbances.

The purpose of the study is to acknowledge the impact of the described current situation on the concept of national security and its transformation in the course of ongoing global processes. The tasks are to acknowledge the impact of Europe's "open door" policy, comprehend the progress of Europe's common security policies and estimate how successful it can be in the fast changing environment of today's world. The author uses analytical synthesis and a number of scientific research methods to fulfil the tasks of the thesis and draw conclusions. Expert interviews were extensively performed to gather the opinion of field professionals.

The study clearly indicates that Europe has comprehended the necessity of common security and defence policy. However alternating global situation withhold the progress and success of the implementation of this policy. Modification of the threat itself has brought new topics to the agenda of security community.

Europe is sharing economical, energy and other issues but national security still is the field that each nation is left to consider individually. Physically building Europe's security and defence capacity could be an ambitious plan but contemporary situation require radical actions. Nevertheless the most significant dilemma is the balance between sovereignty and common security interests.

KEYWORDS: national security, challenges of globalisation, common security and defence policy, unconventional warfare, implementation of security policy.

\section{Abstract}

The Theoretical and Practical Challenges of European Security Community in the Context of Globalisation

Submitted 04/2017

Accepted for publication 08/2017

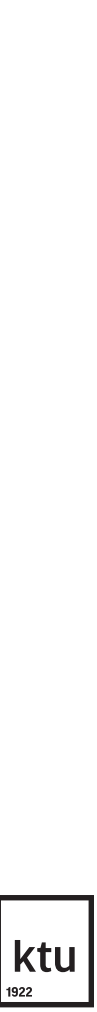

European Integration Studies No. $11 / 2017$

pp. $65-74$

DOI 10.5755/j01.eis.0.11.18129 (c) Kaunas University of Technology 
Oxford dictionary defines term "globalisation" as the process by which businesses or other organizations develop international influence or start operating on an international scale. (Oxford Dictionary, 2017). This definition show classical approach to globalisation as initially economic phenomena. Nevertheless modern world is facing the situation that globalisation as a process has not only economical but also cultural, military and political influence.

The Swedish journalist Thomas Larsson has said that globalization „is the process of the shrinking of the world, the shortening of distances, and the closeness of things. It allows the increased interaction of any person on one part of the world to someone found on the other side of the world, in order to benefit“. He also states that "Globalisation is happening, faster and faster. But it is far from complete, and far from inevitable". (Larsson, 2001). This statement perfectly shows that globalisation should be perceived not as a constant condition or a destination but as a path of development.

Globalisation as a process that directly effects almost all aspects of society also has reshaped the concept on nation-state. Historical concept of the nation-state is that this is an area where the cultural boundaries match up with the political boundaries. The ideal of nation-state is that the state incorporates people of a single ethnic stock and cultural traditions. (Kazancigil, Dogan, 1986).

Now we can say that modern world and the inconsistent process of globalisation have given new dimensions to core of the nation-state - matters like national self-confidence, the values of a certain nation, identification with a certain ethnos, traditions, symbols and history. Those used to be issues that were natural necessity allowing one to be a special part of the community and underlining the singularity of each individual. Nevertheless due to a number of factors borders have ceased to exist literally and figuratively.

During the foundation and enlargement of modern Europe regional policy was mostly economically driven. When in 2009 Secretary General of the Council of the European Union and High Representative for the Common Foreign and Security Policy Javier Solana introduced European Security Strategy it was stated that „Europe has never been so prosperous, so secure nor so free. The violence of the first half of the 20th Century has given way to a period of peace and stability unprecedented in European history". (European Security Strategy, 2003). Today it is clear that this declaration was based on aspects that that the founders and developers of Europe could not anticipate.

Current situation show the need to shift emphasis of policy from economics to security. Moreover security policy should conceive the context of practically unlimited information space, the aggressive propaganda of hostile states (or pseudo states) and endless flow of refugee's that contribute to international terrorism and national disturbances. Additional challenge is the obvious indications and events that refer to the collapse of the common Europe. Brexit and geopolitical interests of Russia have entailed the change of political course of power states like Germany and France. It is clear that previously mentioned "shrinking of the world" is a phenomena that should be considered also in security community.

The described situation encouraged author as a practitioner to set tasks for this research, namely to acknowledge the impact of Europe's "open door" policy, comprehend the progress of Europe's common security policies and estimate how successful it can be in the fast changing environment of today's world.

Author used analytical synthesis and a number of scientific research methods to fulfil the tasks of the thesis and draw conclusions. Analytical and comparative methods were used to analyse literature and legal documents and compare practical studies. Expert interviews were extensively performed to gather the opinion of field professionals from the state security services. Author chose four high and medium rank officers from several state security agencies (due to professional reasons the names and positions of interviewed persons cannot be disclosed). 


\section{Transformation of the concept of national security}

Analysis of security policy starts with comprehension of the concept of national security. Bock and Berkowitz defined national security as "the ability of a nation to protect its internal values from external threats,.. (Bock, Berkowitz, 1966). This historical definition clearly outlines the complexity of current situation in Europe. Defining ,internal values“ and „external threats“ in the diversity of modern Europe is a challenge for policy makers and to even a greater extent to those implementing these policies. More appropriate could be the approach of professor of Transnational Relations, Foreign and Security Policy Helga Haftendorn who states that "there is no one concept of security: national security, international security and global security refer to different sets of issues and have their origins in different historical and philosophical contexts. " (Haftendorn, 1991). Nevertheless European policy makers should find the balance between these "different sets of issues" as for Europe concept of national security has lost its strict borders.

\section{Shift of emphasis from economy to security}

Briefly considering the history it is clear that at the core of The European Union are security reasons. The European Coal and Steel Community was founded with the aim of ending the frequent and bloody wars between neighbours. It begun to unite European countries economically and politically in order to secure lasting peace. These efforts led to period of rapid economic growth that resulted in enlargement of the community. The collapse of communism across central and eastern Europe and the concept of Single Market gave new dimensions to the 'four freedoms' (movement of goods, services, people and money) thus emphasising Europe's economic competences.

The global economic crisis stroke hard in Europe. This brought necessity to work on common financial, energy and transit policies. Current developments also brought new security challenges - annexation of Crimea by Russia, increasing religious extremism in the Middle East and regions around the world, leading to unrest and wars which result in people fleeing their homes and seeking refuge in Europe. Currently European Union is left not only facing the dilemma of how to take care of these security issues, but also found itself the target of several terrorist attacks. (The history of the European Union, 2017).

Subsistent situation dramatically reveal that Europe cannot solemnly concentrate on economic issues but it should also consider evolving threats that it has not faced before. Nowadays every policy that is developed within European Union should consider the actual threats that influence it's member states.

\section{Nature of the threats}

European political and economic security expert Robin Niblett promptly summarised security challenges of European Union involving Russia, the Middle East, refugees, immigration, Brexit, terrorist attacks and a United States president-elect who has called the NATO alliance "obsolete" and came to conclusion that "the list of threats from a European context are all coming together." (Vlasic, 2017).

This listing precisely show the variety of threats that Europe is forced to face and what is more important - also deal with. The analysis of annual reports of several European security services show that those are not only hypothetical threats that are comprehended only by policy makers and theoreticians.

Latvian Security police recently published its annual report that outlined security threats - activities of Russian Federation in the region and international terrorism. First on the agenda is the Russian aggressive foreign policy and active espionage in the region. So called compatriot movement is used by Russia not to preserve the national identity of the diaspora but is an instrument for enforcing the interests of Russian foreign policy and for the power structures to covertly interfere with domestic policy and influence decision-making thus undermining the
Current state of play 
security system of the country in the long run. Manifestation of this soft-power channels through advocacy of Russian rights, benevolent interpretation of socio-political process and history and criticism of NATO activities in the region. (Latvian Security Police Annual report, 2016). International terrorism and refugee crisis is viewed as a consequential threat.

Swedish Security service in process of preparing latest Annual report already released security trends. Security situation in the region is characterised as tense due to several terrorist attacks in Europe and hardened climate in political debates. The nature of the threat to Sweden and Swedish interests has undergone a significant change in the past few years. For example, terrorist profile has changed from interlinked individuals to so-called "lone actors“. The Security Service believes that any terrorist attack in Sweden would probably be carried out by a lone perpetrator. (Swedish Security Service, 2016).

Counter-intelligence together with protective security are also mentioned as key factors of security environment in Sweden. Previous Annual report stated that that foreign intelligence services operated in Sweden to gather intelligence on politics, economics, defence and technology. They specifically targeted the central government, public agencies, the defence system, foreign interests, as well as research and industry. As a novelty in security community Swedish Security service became aware that some of these services engage in so-called refugee espionage. (Swedish Security Service Annual report, 2013).

Estonian Security police in their Annual review stated that one key security impact on Estonia and Europe was deepening confrontation with the Russian Federation owing to an aggressive Russian foreign policy. As well as Latvians also Estonians stress that activities of NATO disturbs Kremlin. As part of unconventional threat Estonian Security police also mentions compatriot policy - a special form of the divisive policy that Russia uses to manipulate expatriate communities. (Estonian Internal Security Service Annual Review, 2016).

But for example in the Spanish National Security Council Annual Report on national security terrorism was named the worst enemy of freedom and democracy and should be countered with strong response and message of unity. Migration and counterintelligence were also mentioned as direct threats. (National Security Council of Spain Annual Report on national Security, 2015).

The analysis of these assessments show obvious shift from conventional threats like organised terrorist groups to unconventional - lone perpetrators. Or with the example of Russia from conventional political battle to unconventional usage of soft-power to influence the policy making process from within.

Practically unlimited information space including social media is also key factor that shape the current security situation. Radicalisation more frequently happens on-line. Social media reaches individuals in countries and regions where Muslims are rarity and locally there are no signs of Islamist extremism. Even in Latvia - country where terrorism threat level has been low - appeared a classical example where 22-yera-old Mārtiňš from a small town in the middle of country in several month time radicalised and went to fight for terrorist organisation „Islamic state“. (Krenberga, 2016).

Latvian Security police in its Annual report allocated special section to Russia usage of information space. For several years Russia using all instruments available in a democratic country launched targeted media operations to systematically gain positions in Latvian information space. The propagators of Russia's aggressive foreign policy with the help of generous funding not only involve in journalism and shape alternative opinions but also launch coordinated activities to influence public opinion in accordance with Russia's geopolitical interests. (Latvian Security Police Annual report, 2016).

Estonia also has stressed The Kremlin's attempts to make greater use of the internet and social media in its anti-West, including anti-Estonian, influence operations. (Estonian Internal Security Service Annual Review, 2016). 
Together with the mentioned there is one more key element that contributes to the security situation. Migration is now mentioned in every threat assessment. Free movement of persons is a complex issue and more detailed analysis of this phenomena can be found in another thesis of the author "Free Movement of the persons as the cause for problems to prevent threats to national security".

\section{Brief history}

The idea of a common security and defence policy for Europe is not new. Several historical events dictated the need for defensive arrangements in Europe thus in 1948 The Western European Union was created. It became the principal forum for consultation and dialogue on security and defence in Europe. To enact the defence provisions of the treaty Western Union Defence Organisation was established. Later it transformed to become „European Pillar" of North Atlantic Treaty Organisation. (Duke, 2000).

Following the end of the Cold War and the subsequent conflicts in the Balkans, it became clear that the European Union needed to assume its responsibilities in the field of conflict prevention and crisis management. The conditions under which military units could be deployed were agreed and the post of the "High Representative for Common Foreign and Security Policy" was created to allow the European Union to speak with 'one face and one voice' on foreign policy matters. (The Common Security and Defence Policy, 2016).

\section{The European Security Strategy}

One of the milestones in the development of European security was adoption of The European Security Strategy in 2003. For the first time Europe analysed the European Union's security environment and identified key security challenges and subsequent political implications for the European Union. European Security Strategy provided the conceptual framework for the Common Foreign and Security Policy that later became the Common Security and Defence Policy.

Though this paper was of advisory nature it outlined the five key threats - terrorism, proliferation of weapons of mass destruction, regional conflicts, and state failure and organised crime. European Security Strategy not only listed the threats but also highlighted the possible interplay between key threats and called for political implications of the new security environment. (European Security Strategy, 2003).

In 2008 this document was revised and the conclusions were not satisfactory. Report on the Implementation of the European Security Strategy reviled that in all five areas progress has been slow and incomplete. More work was required in all areas, necessity to explore a comprehensive EU approach, raise awareness and enhance international co-operation was defined as strategic.

The context of the report demonstrate that European Union remains an anchor of stability and carries greater responsibilities than at any time in its history. Europe faces increasingly complex threats and challenges that is accelerated by globalisation, shifts in power and differences in values. To rise to these new challenges Europe should examine its practice and elaborate on improvement of implementation as the identified range of threats and challenges to its security interests have not gone away but have become more significant and all more complex. (Report on the Implementation of the European Security Strategy, 2008).

\section{Common Security and Defence Policy}

Cornerstone in the development of Common Security and Defence Policy is The Lisbon Treaty that came into force in December 2009. The treaty includes both a mutual assistance (if a Member State is the victim of armed aggression on its territory, the other Member States shall have towards it an obligation of aid and assistance by all the means in their power, in accordance with Article 51 [the 
right to self-defence] of the United Nations Charter. This shall not prejudice the specific character of the security and defence policy of certain Member States' (TEU Art. 42.7) (The Treaty of Lisbon, 2007)) and a solidarity clause (the Union and its Member States shall act jointly in a spirit of solidarity if an EU Member State is the object of a terrorist attack or the victim of a natural or man-made disaster' (TFEU Art. 222) (The Treaty of Lisbon, 2007)) and allowed for the creation of the European External Action Service under the authority of the High Representative of the Union for Foreign Affairs \& Security Policy/Vice-President of the European Commission. This structure allows to bring all the necessary EU assets together and to apply a "comprehensive approach" to EU crisis management as the EU is constantly improving its crisis management capabilities.

European Commission has stated that terrorism, trafficking and smuggling, hybrid threats by state and non-state actors and other threats and challenges that directly affect Europe's internal security and often feed off the crises and instability in the regions surrounding Europe. The necessity to counter these threats and become a stronger actor on the international scene and promote peace and security in its neighbourhood and beyond led to adoption of Global Strategy for the European Union's Foreign and Security Policy. This strategy turn three interlinked decisions on security and defence form vision concrete actions.

European ministers agreed on a new level of ambition in security and defence (Council conclusions on implementing the EU global strategy in the area of security and defence, 2016) focusing on three priorities: enabling the European Union to respond more comprehensively, rapidly and effectively to crises, in particular in our neighbourhood; helping to make our partners stronger when it comes to their security and defence; and strengthening the European Union's capacity to protect European citizens, by working more closely together on security.

European Commission adapted The European Defence Action Plan comprising a European Defence Fund and other actions to help Member States boost research and spend more efficiently on joint defence capabilities, thus fostering a competitive and innovative defence industrial base and contributing to enhance European citizens' security. (Roadmap of the Initiative: European Defence Action Plan, 2015). The Council of the European Union and Foreign Ministers of NATO adopted in parallel a common set of proposals for EU-NATO cooperation. The set of actions comprises 42 concrete proposals for implementation in seven areas of cooperation. (Statement on the implementation of the Joint Declaration signed by the President of the European Council, the President of the European Commission, and the Secretary General of the North Atlantic Treaty Organization, 2016).

The most significant implementer of Common Security and Defence Policy is European External Action Service that acts as he EU's diplomatic service. Its contribution is evident in Report on the implementation of the Common Security and Defence Policy (based on the Annual Report from the Council to the European Parliament on the Common Foreign and Security Policy).

This paper also stresses that European security environment has deteriorated considerably. It has become more fluid, more complex, more dangerous and less predictable. One of the most important conclusions reveal that threats are both conventional and hybrid, generated by both state and non-state actors, and coming from the south and the east, and that they affect the Member States differently though they often have a cross-border dimension. Notion that the security of the EU Member States is deeply interconnected is followed by remark that uncoordinated and fragmented reaction to common threats and risks perplexes and hampers more common approach. It is emphasised that this lack of coordination constitutes one of the vulnerabilities of the Union's action. The report underlines that, as Europe is no longer in full control of its security environment, Common Security and Defence Policy tools should be used more efficiently, Member states should work on cooperation and coordination and have more integrated approach to crises. (Report on the implementation of the Common Security and Defence Policy, 2016). 
It is clear that Europe long before has comprehended the necessity for common security policy. Nevertheless there are several drawbacks that withhold the successful implementation and action of European common security policies.

Report on the implementation of the Common Security and Defence Policy states that "EU citizens would like to see greater EU engagement in matters of security and defence policy“. (Report on the implementation of the Common Security and Defence Policy, 2016). High Representative/ Vice President Federica Mogherini said that "For most Europeans security is a top priority today". (EU Security and Defence package, 2016). She also called Europe to work on „collective sense of direction" to fulfil the political goals that are elaborately set.

The need for cooperation and common understanding of the threats was stated also in European Security Strategy. There it was said that EU needs to be more active, more coherent and more capable. The importance of international cooperation and EU partnerships is also emphasised by claiming that none of the threats can be tackled by the Union alone. The conclusion reaffirms that these challenges also pose opportunities for the EU to become more active and more capable in the pursuit of a safer, more unified world. (European Security Strategy, 2003).

In the previous chapter author analysed the annual reports of several security services that can be generalised to particular EU Member states and it was clear that range of the threats to these states is actually the same. Policies mentioned previously also apply to these states. Though there is common comprehension of the threat, the lack of common vision how to counter the threat hinders the success of the common security policies.

Senior researcher at Zurich Eidgenossische Technische Hochschule Centre for Security Studies Daniel Keohane promptly draw together the reasons behind the failure of the security policies. He indicates that „EU defence policy was conceived as a crisis management, in theory to be able to do everything but territorial defence. But these days EU defence policy seems to do everything but crisis management. The paradox of Europe's defence policy is that the strategic demand for EU action has been growing but political interest in national capitals in acting through the EU's defence policy has been declining." (Keohane, 2016).

Keohane's list of reasons for this paradox is rather comprehensive. Firstly, different European capitals have different political priorities. Secondly, Europeans suffer from a serious lack of strategic consensus. Thirdly, there is an emerging geographic divide between those governments focused on the challenge of Russia and those concentrated on the threats emanating from the Middle East and North Africa. And finally, divisions between the 'big three' - France, Germany, and the UK - has enormous impact on EU defence policy as they collectively account for almost two-thirds of EU defence spending. (Keohane, 2016).

This is another turning-point. Shift of focus in the security and defence policies of traditional trend-setters like Germany and France has opened another perspective of potential threat to security. Several security experts already have claimed that change of security policy in France and Germany together with Brexit has given Russian new potential for development and execution of its hostile and aggressive foreign policy in Europe. (Interviews with state security officers, 2017).

Carnegie Europe editor in chief Judy Dempsey in a panel discussion on security issues asked the panellists (active or former top diplomats from Europe and North America) to name the most important security threat to their respective countries. Here is what they came up with: (1) Lack of confidence, (2) the de-linkage across the Atlantic, (3) lack of public resilience, and (4) the undermining of European solidarity. (Dempsey, 2012).

EU Institute for Security Studies also emphasised that ,the future of Common Security and Defence Policy is not solely predicated on the capacity of the Europeans to work together, but al- 
most as crucially on their ability to work with others. (European and security and defence policy. The first 10 years (1999-2009), 2009).

It is obvious that common vision and sense of solidarity is crucial. Nevertheless another key element for Europe's success is subjected to ability of building and maintain positive relations with strategic partners. Current situation in Europe clearly show that in this form and with this attitude Europe will not reach the common goal of "secure and prosperous Europe".

In a sense The European Union is a unique partnership where member states have pooled sovereignty in certain policy areas to counter the matters that ask for common vision and action without jeopardising their national identity and self-determination. On contrary, further generalisation of European policies and creation of immense common capacities inevitably will lead to total or partial loss of sovereignty.

Professor at European Institute of Public Administration and Senior Fellow of Maastricht University Simon Duke has elaborated on the idea of a federal Europe and concluded that ", the ideas of federal Europe enjoy a long history of intellectual endeavour. The notion of a unified and prosperous Europe is one that came to the fore in the mid-nineteen century. (..) Not all agreed though on how a federal Europe should be organised or how to attain a united Europe." (Duke, 2000).

From the security perspective this could be one of the best ways to deal with common security threats. In the course of developing this thesis author came to conclusion that this point in history could become also the turning point of European security community transforming it form sporadic national formations to unified Common Security Capacity that could successfully implement common security policies. In this model security policy from declarative paper becomes fully-fleshed defence mechanism.

Author concludes that Europe needs extensive audit of the security policies and an updated threat assessment that would allow any member states to find position in current threat situation and decide to what extent it involves in this common policy. This can be achieved only if each member state clarifies to what extent it is ready to engage in common policies and what they expect from these policies. It is clear that at one point Europe will have to understand whether it follows the traditional values of European Union like solidarity and mutual assistance or sets new list of values that are more appropriate for member states.

\section{Conclusions}

_ Globalisation as a process has approximated the threat creating security situations and challenges that did not exist.

- Historical concepts like "internal values" and "external threats" have lost its direct and unambiguous meaning leaving wide space for interpretations.

_ Security is not comprehended only as element of economic development but has become separate discipline that is as important as economy or at some point even more important.

- European countries have comprehended that they should begin with identifying the threats, then set the counter measures and deal with the threats. At first two points Europe is excellent.

- Experts as well as politicians share the views on current threats naming Russian hostile activities, international terrorism and migration as key issues.

_ Members of European security community have comprehended the enormous impact of unlimited information space on the current security situation. It insubstantial whether country concentrates on Russian foreign policy or international terrorism.

Idea of common security basis follows development of European Union from its foundation. Numerous security policies have been created and to some extent implemented but there have been 
drawbacks that did not allow these policies to be implemented fully.

Security policy defines the threats and sets the measures but the governments of member states are the ones who brings these policies into action. For the policy to be successful mutual assistance and solidarity should not be mere declarations.

- To some extent Europe should acknowledge that it has partially lost control of current security situation as the threats themselves and the ways they are realised are changing at enormous speed.

- Though the member states are subject to one security policy the comprehension of the threats varies form country to country, for region to region.

- Internal and external cooperation, sense of common direction, coherent actions and strong answer are key elements to make European common security policies successful.

_ Europe will have to understand whether it follows the traditional values of European Union like solidarity and mutual assistance or sets new list of values that are more appropriate for member states.

Bock, P.J., Berkowitz, M. (2000) American national security: a reader in theory and policy, 134

Dempsey, J. (2012) The Four Threats to European Security. (Retrieved from http://carnegieeurope. eu/strategiceurope/?fa=49541)

Drošîbas policija. (2016) Gada publiskais pārskats. (retieved from http://www.dp.gov.lv/lv/)

Duke, S. (2000) The Elusive quest for European Security. From EDC to CFSP, 14 https://doi.org/10.1057/9780230509672

Estonian Internal Security Service. (2016) Annual Review. (retrieved from https://www.kapo.ee/en/ content/annual-reviews.html)

European Commission. (2015) Roadmap of the Initiative: European Defence Action Plan (retrieved from http://ec.europa.eu/smart-regulation/ roadmaps/docs/2016_grow_006_cwp_european_defence_action_plan_en.pdf)

European Council. (2003) European Security Strategy. A secure Europe in a better world. (Retrieved European Council. (2008) Report on the Implementation of the European Security Strategy. Providing Security in a changing world. (Retrieved from http://www.consilium.europa.eu/ueDocs/cms_ Data/docs/pressdata/EN/reports/104630.pdf)

European Council. (2016) Press Release - Council conclusions on implementing the EU global strategy in the area of security and defence (retrieved from http://www.consilium.europa.eu/en/press/ press-releases/2016/11/14-conclusions-eu-global-strategy-security-defence/)

European Parliament. (2016) Report on the implementation of the Common Security and Defence Policy. (Retrieved from http://www.europarl.europa.eu/sides/getDoc.do?type=REPORT\&reference $=$ A8-2016-0317\&language $=E N$ )
European Union. (2017) The history of the European Union. (retrieved from https://europa.eu/european-union/about-eu/history_en)

European Union. (2007) The Treaty of Lisbon. (Retrieved from http://eur-lex.europa.eu/legal-content/en/TXT/?uri=CELEX:12007L/TXT)

European Union External Action Service. (2016) The Common Security and Defence Policy. (Retrieved from https://eeas.europa.eu/headquarters/headquarters-homepage_en/431/The $\% 20$ Common\%20Security\%20and\%20Defence $\% 20$ Policy\%20\%28CSDP\%29)

European Union External Action Service. (2016) EU Security and Defence package. (Retrieved from https://eeas.europa.eu/headquarters/headquarters-homepage_en/16693/EU\%20Security\%20 and\%20Defence\%20package)

European Union Institute for Security Studies. (2009) European and security and defence policy. The first 10 years (1999-2009), 13

Haftendorn, H. (1991) The Security Puzzle: Theory-Building and Discipline-Building in International Security, 3.

Kazancigil, A., Dogan, M.,(1986) The State in Global Perspective; Comparing Nations: Concepts, Strategies, Substance, 188.Keohane, D., (2016) The paradox of EU defence policy (retrieved from https:// www.europeangeostrategy.org/2016/03/the-paradox-of-eu-defence-policy/)

Krenberga, O. (2016) Ekskluzīva intervija ar «Daīš» savervēto Mārtinu: Esmu vīlies «Islāma valstī». (retrieved from http://www.lsm.lv/lv/raksts/latvija/zinas/ekskluziva-intervija-ar-dais-saverveto-martinu-esmu-vilies-islama-valsti.a216068/)

Larsson, T. (2001) The Race to the top. The real story of globalization, 3

\section{References}


National Security Council of Spain. (2015) Annual Report on national Security. (retrieved from http:// www.dsn.gob.es/en/documento/informe-anual-seguridad-nacional-2015)

North Atlantic Treaty Organization. (2016) Statement on the implementation of the Joint Declaration signed by the President of the European Council, the President of the European Commission, and the Secretary General of the North Atlantic Treaty Organization. (Retrieved from http://www.nato.int/ cps/en/natohq/official_texts_138829.htm)

Oxford University Press. (2017) Oxford Dictionary. (Retrieved from https://en.oxforddictionaries. com/definition/globalization)
SwedishSecurityService. (2013) Annual Report(retrieved from http://www.sakerhetspolisen.se/download/18.4f0385ee143058a61a81622/1400770540371/ Sapo2013_ENG_webb.pdf)

Swedish Security Service. (2017) Launch of the Swedish Security Service 2016 yearbook. (retrieved from http://www.sakerhetspolisen.se/en/swedish-security-service/about-us/current-events/ news/2017-03-16-launch-of-the-swedish-security-service-2016-yearbook.html)

Vlasic, M. (2017) The Global Security Outlook. Comments on World Economic Forum. (retrieved from https://www.weforum.org/agenda/2017/02/the-global-security-outlook/)

\section{About the author \\ KEINIS VIRGINIJS \\ Mg.lur. (Doctoral Law student) \\ Rīga Stradinš̌ University}

\section{Fields of research interests}

Law studies, politics, security policies

\section{Address}

16 Dzirciema Street, Rīga

LV-1007, Latvia

E-mail:virginijs.keinis@gmail.com 